\title{
Production of Xylanase from Arthrobacter sp. MTCC 6915 Using Saw Dust As Substrate under Solid State Fermentation
}

\author{
Sevanan Murugan, Donna Arnold, Uma Devi Pongiya, and P.M. Narayanan \\ Microbiology Laboratory, School of Biotechnology and Health Sciences, Karunya University, Karunya Nagar, 641114, \\ Coimbatore, India \\ Correspondence should be addressed to Sevanan Murugan, micromurugans@gmail.com
}

Received 17 May 2011; Revised 1 July 2011; Accepted 8 August 2011

Academic Editor: Roberto Fernandez Lafuente

Copyright ( $\odot 2011$ Sevanan Murugan et al. This is an open access article distributed under the Creative Commons Attribution License, which permits unrestricted use, distribution, and reproduction in any medium, provided the original work is properly cited.

\begin{abstract}
Saw dust was used as substrate for xylanase production from Arthrobacter sp. MTCC 6915. The study of period of incubation, temperature, $\mathrm{pH}$, carbon, and nitrogen sources for xylanase production was optimized. Xylanase production was found to be optimum at an incubation period of $96 \mathrm{hrs}(117.0 \mathrm{U} / \mathrm{mL})$, temperature $30^{\circ} \mathrm{C}(105.0 \mathrm{U} / \mathrm{mL})$, and $\mathrm{pH} 9.0(102.9 \mathrm{U} / \mathrm{mL})$. The results showed that the xylanase production was found to be higher in the presence of carboxymethylcellulose $(176.4 \mathrm{U} / \mathrm{mL}) \mathrm{and}$ dextrose $(126.0 \mathrm{U} / \mathrm{mL})$. It was also observed that peptone $(170.1 \mathrm{U} / \mathrm{mL})$ and beef extract $(161.7 \mathrm{U} / \mathrm{mL})$ supported maximum xylanase production. The enzyme was characterized and found to be fairly active at $\mathrm{pH} 9(764.4 \mathrm{U} / \mathrm{mL})$ and temperature $60^{\circ} \mathrm{C}(819 \mathrm{U} / \mathrm{mL})$. Even in the present study, a major difference in the production temperature $\left(30^{\circ} \mathrm{C}\right)$ and optimal temperature $\left(60^{\circ} \mathrm{C}\right)$ of the enzyme activity was observed. However, the $\mathrm{pH}$ of the production media and the enzyme activity were found to be the same ( $\mathrm{pH} 9$ ).
\end{abstract}

\section{Introduction}

Xylanases (endo-1,4- $\beta$-D-xylan xylanohydrolase) a group of hemicellulolytic enzymes are required for the hydrolysis of $\beta-1,4$ xylans present in lignocellulosic materials [1]. Xylanase enzymes are extracellular enzymes produced by microorganisms [2], and recently, they have aroused great interest due to their potential application in many industrial processes. The potential applications of xylanase include bleaching noncotton cellulosic fibres, melting hemp and linen fibres, clarifying fruit juice and wines [3] and also increasing the brightness of pulp, breaking up the dough, production of hydrolysates from agro industrial wastes [1], and improvement of nutritional properties in lignocellulosic feed stuff [4].

Most studies on the production of xylanases have been performed in submerged liquid culture, and only few works have been reported on xylanase production in SSF using lignocellulosic wastes [5-7]. A number of different sources, including bacteria [8], actinomycetes [9], and yeast [10], have been reported for xylanase production under solid state fermentation (SSF). The most commonly used partial purification of the xylanase enzyme was done using ammonium sulphate precipitation followed by dialysis, since it is highly soluble and nontoxic to proteins and low priced [11]. Chivero et al. [12] and Somogyi [13] used ion exchange chromatography for the purification of xylanase enzyme. The high cost of production of the enzymes has hindered the industrial applications of bioconversion of xylan. It has been reported that several Arthrobacter sp. can reduce hexavalent chromium [14], and they are also known to degrade agricultural pesticides and also agricultural wastes [15]. Lignocellulosic substrates being cheap and readily available have now gained considerable interest because of their possible use in secondary fermentation process. Various lignocellulosic substrates involves agricultural waste materials like corn meal, corn cob, wheat bran, rice husk, rice straw, and bagassae and other lignocellulosic materials like sawdust, vegetable garbage, and cellulose can be used as solid state substrates for the production of xylanase enzyme [16]. The purpose of this work was to produce xylanase from Arthrobacter sp MTCC 6915 under solid-state fermentation using saw dust as substrate and also to study the influence of conditions of fermentation in enhancing the production 
of the enzyme and the effect of metal ion concentration on xylanase and also to determine the effect of $\mathrm{pH}$ and temperature on the catalytic activity of partially purified xylanase.

\section{Materials and Methods}

2.1. Microorganism. Arthrobacter sp MTCC 6915 was obtained from Institute of Microbial Technology (IMTECH), Chandigarh, India. The culture was stored at $4^{\circ} \mathrm{C}$. It was sub cultured at four week intervals.

2.2. Inoculum and Substrate Preparation. $100 \mathrm{~mL}$ of $2 \% \mathrm{nu}-$ trient broth solution (Hi-Media, Mumbai) was sterilized at $121^{\circ} \mathrm{C}$ for $15 \mathrm{~min}$, cooled, and inoculated under aseptic condition with Arthrobacter sp MTCC 6915 from nutrient agar slant which was stored at $4^{\circ} \mathrm{C}$. The broth culture was incubated for 24 hours at ambient temperature.

Saw dust was obtained from the timber industries in Coimbatore, South India. The substrate saw dust was then washed 2-3 times with distilled water and then boiled with distilled water for about 15 minutes. The substrate was dried in an oven and powdered. The powder was sieved using a 40 micron mesh and stored at $-20^{\circ} \mathrm{C}$ until used.

2.3. Enzyme Production in Solid-State Fermentation (SSF). Erlenmeyer flask $(250 \mathrm{~mL})$ containing $5 \mathrm{~g}$ of sawdust was added to $15 \mathrm{~mL}$ mineral basal salt solution (MBSS) medium with the substrate to moisture ratio $1: 3$. The production media was prepared with the following composition (g/L) NaCl, 30.0; KCl, 0.75; $\mathrm{MgSO}_{4}, 7.00 ; \mathrm{NH}_{4} \mathrm{Cl}, 0.5$; $\mathrm{K}_{2} \mathrm{HPO}_{4}(10 \%), \quad 7.00 \mathrm{~mL} ; \mathrm{KH}_{2} \mathrm{PO}_{4}(10 \%), 3.00 \mathrm{~mL}$ and trace metal solution (mg/L): $\mathrm{H}_{3} \mathrm{BO}_{3}, 2.83 ; \mathrm{MnCl}_{2} \cdot 7 \mathrm{H}_{2} \mathrm{O}$, 1.80; $\mathrm{FeSO}_{4} \cdot 7 \mathrm{H}_{2} \mathrm{O}, 2.49$; Na- K-Tartarate, 1.77; $\mathrm{CuCl}_{2}, 0.33$; $\mathrm{ZnCl}_{2}, 0.02 ; \mathrm{CoCl}_{2}, 0.04$ and $\mathrm{Na}_{2} \mathrm{MoO}_{4} \cdot 2 \mathrm{H}_{2} \mathrm{O}, 0.02$. The medium and trace metal solutions were autoclaved separately. The flasks were cooled down to room temperature, and a known amount of sterilized trace elements were added. The flask was inoculated with $1 \mathrm{~mL}$ of inoculum and the content of the flasks were mixed thoroughly to ensure uniform distribution of the inoculum and incubated at room temperature for $24 \mathrm{hrs}$.

2.4. Optimization of Process Parameters. The various process parameters that influence the enzyme production during SSF were optimized over a wide range. The strategy adopted for standardization of fermentation parameters was to evaluate the effect of an individual parameter and to incorporate it at standardized level before standardizing the next parameter. The effect of incubation period on enzyme activity was examined at different time intervals namely 24, 48, 72, 96, 120 , and $144 \mathrm{hrs}$, respectively, at ambient temperature (28 $\pm 2^{\circ} \mathrm{C}$ ) and $\mathrm{pH}$ 7.0. The effect of temperature on enzyme activity was examined at $20^{\circ} \mathrm{C}, 25^{\circ} \mathrm{C}, 30^{\circ} \mathrm{C}, 35^{\circ} \mathrm{C}$, and $40^{\circ} \mathrm{C}$ at pH 7.0 for 96 hours (optimal incubation period). Similarly, the effect of $\mathrm{pH}$ on enzyme activity was examined at different $\mathrm{pH}$ namely $6,7,8,9$, and 10 , respectively.

The effect of supplementation of additional carbon and nitrogen sources to saw dust was examined using carbon sources consisting of carboxymethylcellulose, dextrose, lactose, and sucrose $(1 \%-5 \%)$. Similarly, the nitrogen sources examined were potassium nitrate $\left(\mathrm{KNO}_{3}\right)$, ammonium sulphate $\left[\left(\mathrm{NH}_{4}\right)_{2} \mathrm{SO}_{4}\right]$, beef extract, and peptone $(1 \%-5 \%)$. The optimum concentration of the carbon and nitrogen sources was also determined. The synergistic effect of various carbon and nitrogen sources which showed high xylanase activity was also examined to determine the best combination of carbon and nitrogen sources for the xylanase activity. The combined carbon and nitrogen sources include carboxymethylcellulose and peptone, carboxymethylcellulose and beef extract, dextrose and peptone, and dextrose and beef extract. For the same supplementation studies, the enzyme production was carried out at optimum temperature $\left(30^{\circ} \mathrm{C}\right)$ and $\mathrm{pH} 9.0$ for 96 hours.

2.5. Preparation of Enzymes. Erlenmeyer flask (500 mL) containing $10 \mathrm{~g}$ of sawdust and $30 \mathrm{~mL}$ of MBSS, $\mathrm{pH} 9.0$ along with the carbon and nitrogen sources required for the production of the enzyme was sterilized, cooled, and inoculated with $1 \mathrm{~mL}$ of the pregrown culture of Arthrobacter sp MTCC 6915 in nutrient broth. The flasks were incubated at room temperature for 96 hours, and the enzyme was extracted using Glycine-NaOH buffer.

2.6. Enzymatic Assay. The xylanase activity was assayed using $1 \%$ birchwood xylan as the substrate. $1 \%$ xylan was dissolved in $50 \mathrm{mM}$ Glycine- $\mathrm{NaOH}$ buffer ( $\mathrm{pH}$ 9.0). The reaction mixture containing $40 \mu \mathrm{L}$ of an appropriate dilution of the enzyme and $1 \mathrm{~mL}$ of the substrate was incubated for $10 \mathrm{~min}$. The amount of reducing sugars liberated was determined by using 3,5-dinitrosalicylic acid method (DNS method) [17]. The absorbance of the reference samples (substrate solution incubated without enzyme and diluted enzyme solution in buffer) was deduced from the values of the test samples which were measured by monitoring the optical density at $540 \mathrm{~nm}$. The unit of xylanase activity was defined as the number of $\mu$ moles of reducing sugars formed (measured as xylose) per min under the assay conditions.

\section{Enzyme Activity}

$$
\begin{aligned}
= & \frac{\mathrm{g} \text { of maltose released }}{\text { Volume of enzyme used } \times \text { Time of assay }} \\
& \times \frac{\text { Total volume of assay }(\mathrm{mL})}{\text { Volume used in Colorimetric determination }} .
\end{aligned}
$$

\subsection{Purification of the Enzyme}

2.7.1. Partial Purification by Ammonium Sulphate Precipitation. The contents of the flask were suspended in $100 \mathrm{~mL}$ of $50 \mathrm{mM}$ Glycine-NaOH buffer ( $\mathrm{pH}$ 9) vortexed thoroughly and centrifuged $\left(10,000 \mathrm{rpm}\right.$ for $\left.10 \mathrm{~min}, 4^{\circ} \mathrm{C}\right)$. All proteins are precipitated by ammonium sulphate [18]. About $100 \mathrm{~mL}$ of culture filtrate was treated with $52.3 \mathrm{~g}$ of ammonium sulphate to give $80 \%$ saturation and most of the proteins were precipitated out. This was left overnight, and the precipitate was collected by centrifugation at $10,000 \mathrm{rpm}$ 
for $10 \mathrm{~min}$ [12]. The precipitate was dissolved in phosphate buffer $(50 \mathrm{mM}, \mathrm{pH} 8.0)$, and the enzyme activity was determined in both the precipitate and supernatant. The sample having maximum enzyme activity was used for further studies.

2.7.2. Dialysis. The precipitate obtained was dissolved in phosphate buffer ( $50 \mathrm{mM}, \mathrm{pH} 8.0$ ), and the supernatant was dialysed against the same buffer for 24 hours. Dialysis was carried out using cellulose tubing (molecular weight cutoff $13,000 \mathrm{kDa}$ ). The enzyme activity was determined in both the precipitate and supernatant. The sample (precipitate) having maximum enzyme activity was used for further studies $[12,18]$.

2.7.3. Ion Exchange Chromatography. Concentrated enzyme was loaded onto a anion exchange DEAE Sepharose FF (Sigma-Aldrich Co, USA) column $(15 \mathrm{~mm}$ diameter and height $100 \mathrm{~mm}$ ) at a flow rate of $0.5 \mathrm{~mL} / \mathrm{min}$. Equilibration and elution were performed first with $0.05 \mathrm{M} \mathrm{Na}$-Phosphate buffer to remove unbound proteins and then with a linear salt gradient from 0 to $3 \mathrm{M} \mathrm{NaCl}$. Fractions were collected and analysed for xylanase activity and protein content. Active fractions were pooled and concentrated and then purified using cation exchange CM Sepharose FF (Sigma-Aldrich Co, USA) column. The active fractions were pooled and used for further studies [11].

2.8. Enzyme Characterization-Temperature and $p H$ Profile. The optimal temperature for the purified xylanase was obtained by assaying the enzyme activity at different temperatures $50^{\circ} \mathrm{C}, 60^{\circ} \mathrm{C}, 70^{\circ} \mathrm{C}, 80^{\circ} \mathrm{C}, 90^{\circ} \mathrm{C}$, and $100^{\circ} \mathrm{C}$ at $\mathrm{pH}$ 9.0. At each temperature, the enzyme $40 \mu \mathrm{L}$ along with $1 \mathrm{~mL}$ of substrate (birchwood xylan) was incubated for 40 mins. The residual activity of the enzyme was measured at $540 \mathrm{~nm}$. Similarly, the relative xylanase activity using $1 \%$ $(\mathrm{w} / \mathrm{v})$ birchwood xylan was determined at various $\mathrm{pH}$ levels. The $\mathrm{pH}$ range used varied from 4 to 11 . Three different buffers $(0.05 \mathrm{M})$ were used. Citrate buffer was used for $\mathrm{pH} 4$ to 6, Phosphate buffer was used for $\mathrm{pH} 7$ and 8 , and glycine$\mathrm{NaOH}$ buffer was used for $\mathrm{pH} 9$ to 11 . The enzyme, along with the substrate and the respective buffers, was incubated for $60^{\circ} \mathrm{C}$ at 3 hours. The residual activity of the enzyme was measured at $540 \mathrm{~nm}$.

2.9. Effect of Metal Ion Concentration. Enzyme was incubated with $1 \mathrm{mM}$ solution of the following metal salts such as $\mathrm{CaCl}_{2}, \mathrm{MgCl}_{2}, \mathrm{MgSO}_{4}, \mathrm{HgCl}_{2}, \mathrm{FeSO}_{4}, \mathrm{CuCl}_{2}$, and $\mathrm{ZnCl}_{2}$ and metal chelator such as EDTA for 1 hour at room temperature $\left(28 \pm 2^{\circ} \mathrm{C}\right)$. The residual activity of the enzyme was measured at $540 \mathrm{~nm}$.

\section{Results and Discussion}

3.1. Optimization of Process Parameters. The substrate used in the present study was saw dust, and when grown on saw dust, the maximum enzyme production observed was at $96 \mathrm{hrs}(117.6 \mathrm{U} / \mathrm{mL})$ for every 24 hours at $540 \mathrm{~nm}$. Only

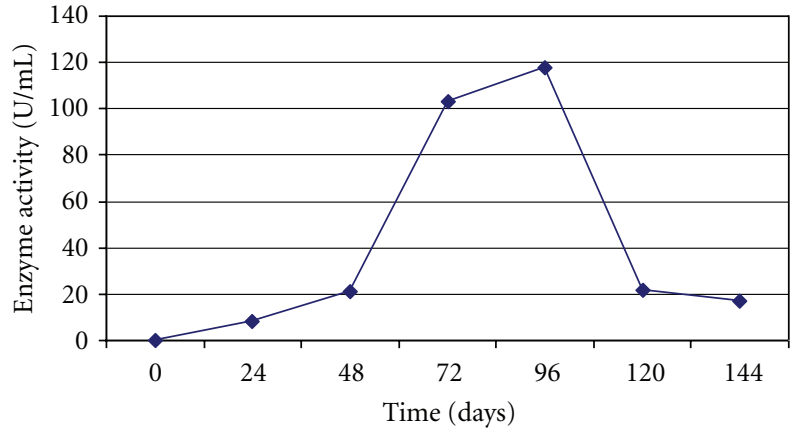

FIGURE 1: Effect of incubation period on xylanase activity of Arthrobacter sp MTCC 6915 using saw dust as substrate.

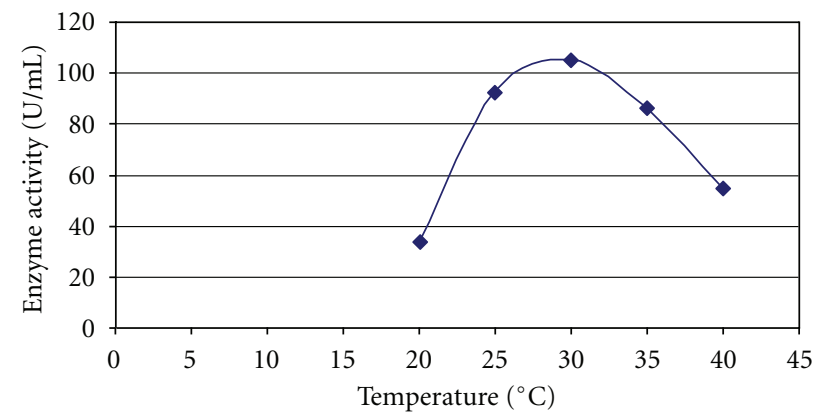

FIGURE 2: Effect of temperature on xylanase activity of Arthrobacter sp MTCC 6915 using saw dust as substrate.

small quantities of xylanase were produced during first $24 \mathrm{hrs}(8.4 \mathrm{U} / \mathrm{mL})$ of fermentation but xylanase production rapidly increased between 48 and 96 hrs (Figure 1). Whereas Aspergillus niger when grown on rice straw under solid state fermentation showed maximum xylanase production after $120 \mathrm{hrs}$ of incubation [19]. Penicillium oxalicum when grown on wheat bran under solid state fermentation, showed maximum production after $144 \mathrm{hrs}$ [20].

The level of increasing xylanase activity $(105.0 \mathrm{U} / \mathrm{mL})$ was found to be optimum at $30^{\circ} \mathrm{C}$. However, increase in temperature beyond $30^{\circ} \mathrm{C}$ led to a decline in the production of enzyme. At a temperature of $25^{\circ} \mathrm{C}(92.4 \mathrm{U} / \mathrm{mL})$, the enzyme activity was found to be little lower than that at $30^{\circ} \mathrm{C}$. The minimum activity was, however, found to be at $20^{\circ} \mathrm{C}$ $(33.6 \mathrm{U} / \mathrm{mL})$ (Figure 2). Similar results were observed, when Arthrobacter sp MTCC 5214 was grown on wheat bran [18].

The highest enzyme activity was found to be optimum at $\mathrm{pH} 9(102.9 \mathrm{U} / \mathrm{mL})$ and minimum at $\mathrm{pH} 6(16.8 \mathrm{U} / \mathrm{mL})$ (Figure 3). Xylanase at $\mathrm{pH}$ value 7-9 makes it suitable for bioleaching applications. Among the xylanases from Bacillus sp, highest $\mathrm{pH}$ optima had been reported for Bacillus Tar1, C-125 and Bacillus sp. NCL-86-6-10 [21, 22]. However, several alkaline-tolerant fungal xylanases have also been characterized [23-25]. Thus, the results of the current study are in accordance with the previous reports.

The impact of supplementation of external carbon source at $1 \%-5 \%$ concentration on xylanase activity was studied, in which four different carbon sources were examined and 


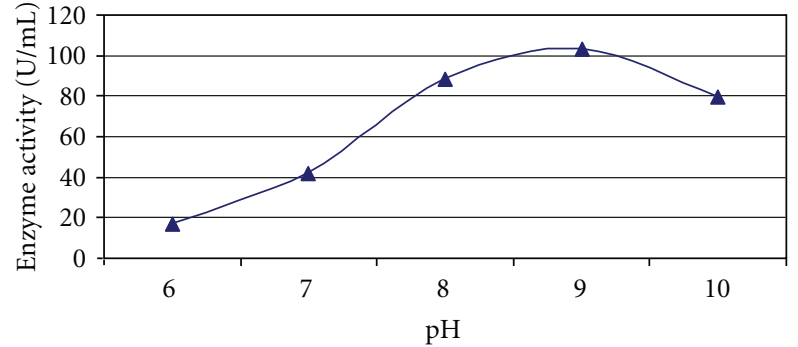

Figure 3: Effect of $\mathrm{pH}$ on xylanase activity of Arthrobacter sp. MTCC 6915 using saw dust as substrate.

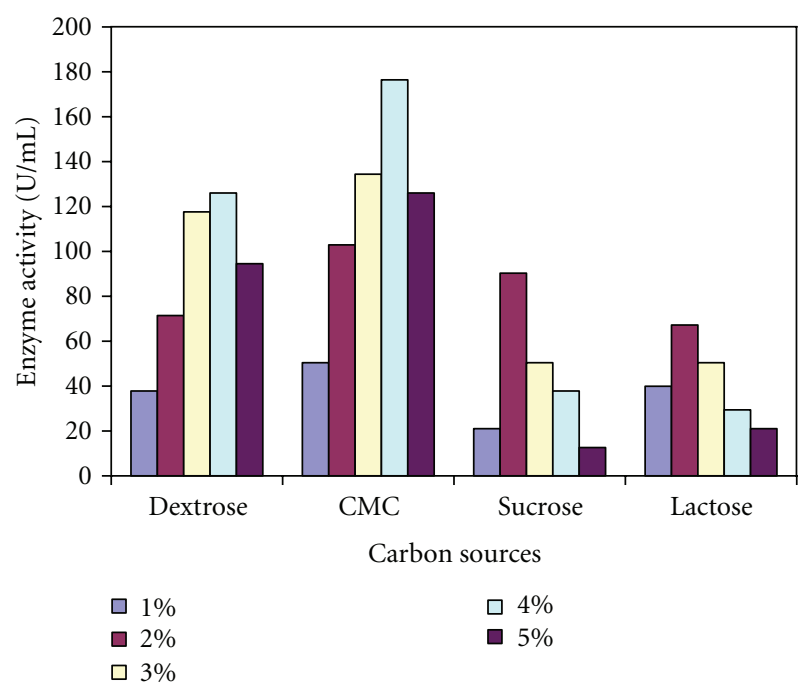

FIGURE 4: Effect of carbon sources on xylanase activity of Arthrobacter sp. MTCC 6915 using saw dust as substrate.

the results are shown in Figure 4. All the carbon sources decreased the xylanase activity at 5\%. The decreases may also be caused by the complex carbon sources present in the production media. On the basis of analyzing the results, it may be concluded that the microorganisms necessitate a low level of carbon in order to produce enzymes, because they are the limiting factor. Among the four sources selected, $4 \%$ of carboxymethylcellulose $(176.4 \mathrm{U} / \mathrm{mL})$ was found to exhibit the maximum enzymatic activity. Similarly, $4 \%$ of dextrose $(126.0 \mathrm{U} / \mathrm{mL})$ also showed relatively higher, however, found lower than that of carboxymethylcellulose. Sucrose and lactose showed very low enzymatic activity. In the present study, it was found that $4 \%$ carboxymethylcellulose and dextrose are the good sources for the production of xylanase enzyme (Figure 4). Effect of carbon sources on the production of xylanase by $P$. oxalicum showed higher enzyme activity for carboxymethylcellulose, when compared to sucrose, lactose, and glucose [20]. Thus, the supplementation of production media with external carbon source had positive effect on enzyme production by Arthrobacter sp MTCC 6915. This shows that the findings of the current studies are in accordance with the earlier reports.

Among the four nitrogen sources tested 1\% peptone $(170.1 \mathrm{U} / \mathrm{mL})$ was found to exhibit the maximum enzymatic

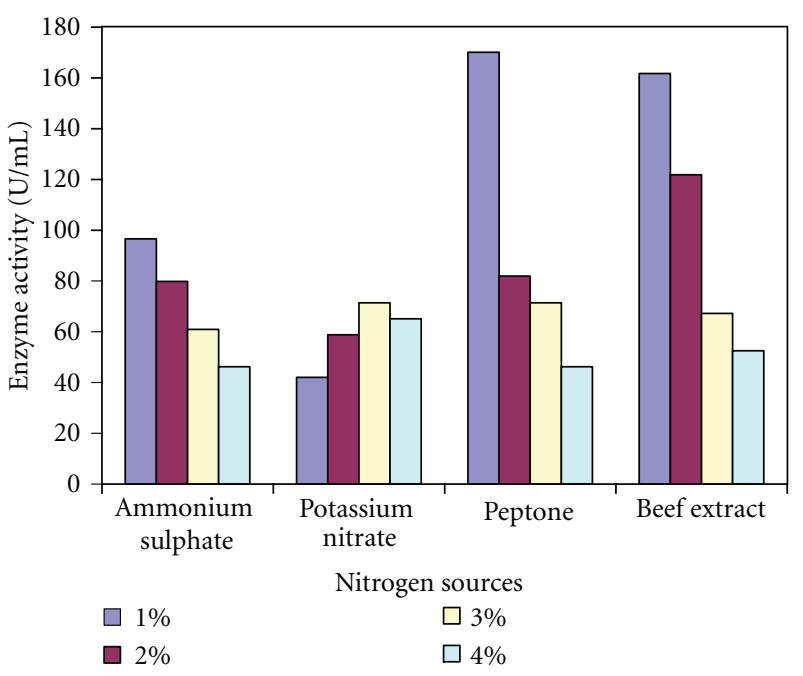

FIGURE 5: Effect of nitrogen sources on xylanase activity of Arthrobacter sp. MTCC 6915 using saw dust as substrate.

activity (Figure 5). Similarly, $1 \%$ beef extract $(161.7 \mathrm{U} / \mathrm{mL}$ ) also showed relatively higher activity, however, lower than that of peptone. Ammonium sulphate and ammonium nitrate showed very low enzymatic activity. In the present study, it was found that $1 \%$ of peptone and beef extract are good supplements for the production of xylanase enzyme (Figure 5). Enterobacter sp MTCC 5112 showed highest xylanase production when the growth medium was supplemented with peptone [18]. Effect of nitrogen sources on production of xylanase by Penicillium oxalicum showed higher enzyme activity for peptone when compared to beef extract, ammonium sulphate, and ammonium nitrate [20]. Thus results of the present study are similar to the earlier findings.

3.2. Synergistic Effects of Various Carbon and Nitrogen Sources. Four different combinations of two carbon (carboxymethylcellulose and dextrose) and nitrogen sources (peptone and beef extract) were taken to determine which combination exhibited the highest enzyme activity. The two carbon sources which exhibited the highest level were $4 \%$ each of carboxymethylcellulose $(176.4 \mathrm{U} / \mathrm{mL})$ and dextrose $(126.0 \mathrm{U} / \mathrm{mL})$ and nitrogen sources $1 \%$ each of peptone $(170.1 \mathrm{U} / \mathrm{mL})$ and beef extract $(161.7 \mathrm{U} / \mathrm{mL})$. It was found that the combination of $4 \%$ dextrose and $1 \%$ peptone exhibited the maximum enzymatic activity $(102.9 \mathrm{U} / \mathrm{mL})$.

3.3. Purification of the Enzyme. The enzyme was isolated, purified, and characterized at room temperature $\left(28 \pm 2^{\circ} \mathrm{C}\right)$. After the partial purification of the enzyme by ammonium sulphate precipitation, the precipitate was separated by centrifugation, then the supernatants and precipitates were subjected to a cellulose tubing bag for dialysis. After the dialysis, enzyme assay was carried out for both the supernatant and precipitate and found that the precipitate $(453.6 \mathrm{U} / \mathrm{mL})$ showed the maximum enzymatic activity which indicates that the enzyme was present in the precipitate. For further 


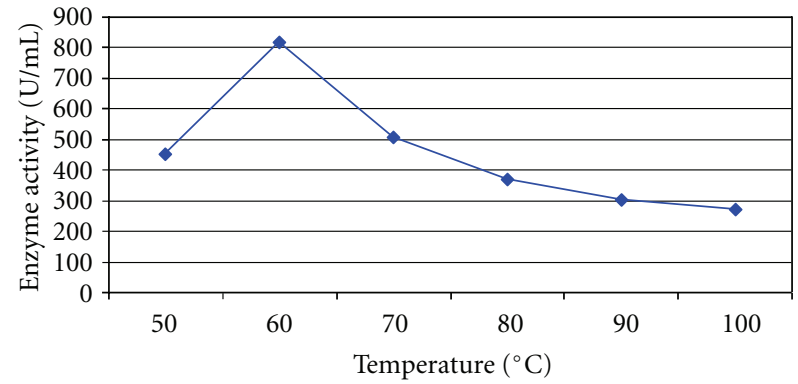

Figure 6: Temperature profile of xylanase activity of Arthrobacter sp. MTCC 6915 using saw dust as substrate.

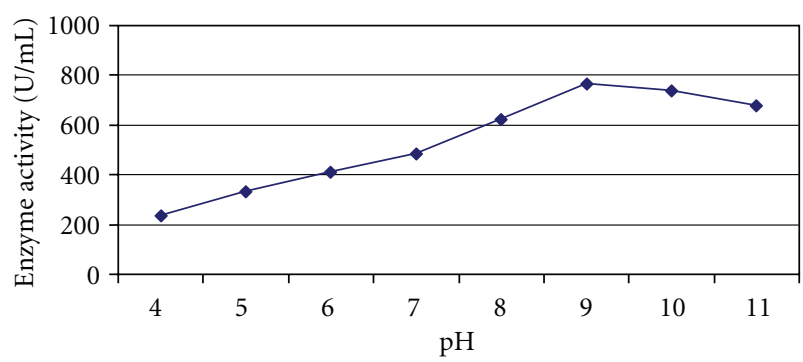

FIGURE 7: pH profile of xylanase activity of Arthrobacter sp. MTCC 6915 using saw dust as substrate.

purification of the enzyme, ion-exchange chromatography was performed [26], and it was found that the precipitate $(804.0 \mathrm{U} / \mathrm{mL})$ retained maximum enzyme activity than compared to the supernatant.

3.4. Enzyme Characterization: Temperature and $p H$ Profile. The maximum enzymatic activity was observed at $\mathrm{pH} 9.0$ $(764.4 \mathrm{U} / \mathrm{mL})$ after 3 hours of incubation. The enzyme activity was considerably higher at $\mathrm{pH} 10.0(739.2 \mathrm{U} / \mathrm{mL})$ but comparatively lesser than at $\mathrm{pH} 9.0$. The enzyme activity decreased greatly and lost most of its activity in acidic $\mathrm{pH}$ range after 3 hours (Figure 6). There are only few bacterial xylanases reported till date with $\mathrm{pH}$ optima of $>9.0$ when grown on solid-state fermentation. Xylanase isolated from Bacillus subtilis which was grown on solid-state fermentation using oat spelt xylan showed maximum activity at $\mathrm{pH} 6.0$ [27]. Xylanase isolated from B. licheniformis A99 [28] had the optimal $\mathrm{pH}$ of 7.0. Similarly, xylanase isolated from $B$. coagulans BL69 grown on soybean residue [29] showed an optimum pH of 7.0. When Arthrobacter sp MTCC 5214 grown on wheat bran showed optimum at $\mathrm{pH} 9.0$ [18]. In view of these observations, the properties of the xylanase produced by Arthrobacter sp MTCC 6915 are much more superior to those reported for xylanases isolated from other bacteria.

Maximum enzymatic activity was observed at temperature of $60^{\circ} \mathrm{C}(819.0 \mathrm{U} / \mathrm{mL})$ after $40 \mathrm{~min}$ incubation. The enzyme activity was considerably higher at $50^{\circ} \mathrm{C}(453 \mathrm{U} / \mathrm{mL})$ and $70^{\circ} \mathrm{C}(508.2 \mathrm{U} / \mathrm{mL})$ though comparatively lesser than $60^{\circ} \mathrm{C}$ (Figure 7). Xylanase isolated from B. coagulans BL69 grown on soybean residue [29] showed activity over a wide
TABLe 1: Effect of Metal Ion Concentration on Xylanase Activity of Arthrobacter sp MTCC 6915 using saw dust as substrate.

\begin{tabular}{lc}
\hline Metal salt solution & Enzyme activity $(\mathrm{U} / \mathrm{mL})$ at $540 \mathrm{~nm}$ \\
\hline $\mathrm{ZnCl}_{2}$ & 168 \\
$\mathrm{FeSO}_{4}$ & 142.8 \\
$\mathrm{MgSO}_{4}$ & 157.6 \\
$\mathrm{MgCl}_{2}$ & 155.4 \\
$\mathrm{CuCl}_{2}$ & 142.8 \\
$\mathrm{HgCl}_{2}$ & 25.2 \\
$\mathrm{CaCl}_{2}$ & 130.2 \\
$\mathrm{EDTA}$ & 10.5 \\
\hline
\end{tabular}

$\mathrm{ZnCl}_{2}$-zinc chloride; $\mathrm{CuCl}_{2}$ - copper chloride; $\mathrm{FeSO}_{4}$-ferrous sulphate; $\mathrm{HgCl}_{2}$ - mercuric chloride; $\mathrm{MgSO}_{4}$ - magnesium sulphate; $\mathrm{CaCl}_{2}$ calcium chloride; EDTA—ethylene diamine tetra acetic acid; $\mathrm{MgCl}_{2}-$ magnesium chloride.

range of temperatures $\left(45^{\circ} \mathrm{C}-75^{\circ} \mathrm{C}\right)$. B. subtilis produced a xylanase enzyme, which had a highest activity at $60^{\circ} \mathrm{C}$ temperature, when grown on oat spelt xylan under solidstate fermentation [27]. Similarly, xylanase obtained from Streptomyces actuosus A-151 grown on rice bran showed optimum temperature of $60^{\circ} \mathrm{C}-70^{\circ} \mathrm{C}$ [30]. Bacillus sp. JB99 grown on rice bran in solid-state fermentation produced xylanase with optimum activity at $50^{\circ} \mathrm{C}[31]$.

3.5. Effect of Metal Ion Concentration. Xylanase activity was assayed in the presence and absence of metal ions, and a metal chelator EDTA. Both $\mathrm{Hg}^{2+}(25.2 \mathrm{U} / \mathrm{mL})$ and EDTA $(10.5 \mathrm{U} / \mathrm{mL})$ inhibited the activity of the xylanase enzyme. The inhibition of the enzyme by $\mathrm{Hg}^{2+}$ ions may be due to its interaction with sulphydryl groups, suggesting that there is an important cysteine residue in or close to the active site of the enzyme. The inhibition of the xylanase activity in the presence of EDTA suggests that metals are needed for the enzymatic reaction. The xylanase activity was greatly elevated by the addition of $\mathrm{Zn}^{2+}, \mathrm{Fe}^{2+}, \mathrm{Cu}^{2+}, \mathrm{Mg}^{2+}$, and $\mathrm{Ca}^{2+}$ ions (Table 1). It is not certain from the above studies, whether these ions/agents could be binding to the enzyme, causing conformational changes that resulted in increased enzyme activity, or the xylanase requires a metal ion on the active site. Nakamura et al. [32] showed that $\mathrm{Hg}^{2+}$ ions inhibited the enzyme activity. Cesar and Mrša [33] for T. lanuginosus showed that $\mathrm{Ca}^{2+}$ enhanced xylanase activity. $\mathrm{Mn}^{2+}$ and $\mathrm{Zn}^{2+}$ ions also had positive effect on xylanase activity [34]. Ghanem et al. [35] for Aspergillus terreus showed that $\mathrm{Ca}^{2+}$ enhanced xylanase activity. Khandeparkar and Bhosle [18] for Enterobacter sp. showed that EDTA inhibited the enzyme activity. Similar results were observed in the present study.

\section{Conclusion}

The results strongly indicate that the SSF system using saw dust as substrate is an economical method for the production of xylanase at extremely low operational cost, as cheap and abundant wastes are generated in the timber industries. Arthrobacter sp MTCC 6915 used in the present study is novel, and there are no published reports on the 
production of xylanase by this culture. However, the amount of enzyme produced by the Arthrobacter sp MTCC 6915 differed with each of the carbon and nitrogen sources. For the efficient solid waste management, this waste can be used at the maximum, as continuous accumulation of industrial waste possess a serious environmental hazard. The xylanase enzyme produced by the Arthrobacter sp MTCC 6915 is thermostable and alkalophilic which has wide industrial applications. The future prospects of this study is that a better thermostable and alkalophilic enzyme can be produced which can be used for industrial applications so that the enzyme can withstand the temperature and the alkaline $\mathrm{pH}$.

\section{References}

[1] P. P. Kheng and I. C. Omar, "Xylanase production by a local fungal isolate Apergillus niger USM AI 1 via solidstate fermentation using palm kernel cake (PKC) as substrate Songklanakarin," Songklanakarin Journal of Science and Technology, vol. 27, pp. 325-336, 2005.

[2] J. Georis, F. Giannotta, E. de Buyl, B. Granier, and J. M. Frère, "Purification and properties of three endo- $\beta-1,4$-xylanases produced by Streptomyces sp. strain S38 which differ in their ability to enhance the bleaching of kraft pulps," Enzyme and Microbial Technology, vol. 26, no. 2-4, pp. 178-186, 2000.

[3] M. Galbe and G. Zacchi, "A review of the production of ethanol from softwood," Applied Microbiology and Biotechnology, vol. 59, no. 6, pp. 618-628, 2002.

[4] R. J. Wallace, S. J. A. Wallace, N. McKain, V. L. Nsereko, and G. F. Hartnell, "Influence of supplementary fibrolytic enzymes on the fermentation of corn and grass silages by mixed ruminal microorganisms in vitro," Journal of Animal Science, vol. 79, no. 7, pp. 1905-1916, 2001.

[5] S. Couri, S. D. C. Terzi, G. A. S. Pinto, S. P. Freitas, and A. C. A. D. Costa, "Hydrolytic enzyme production in solid-state fermentation by Aspergillus niger 3T5B8," Process Biochemistry, vol. 36, no. 3, pp. 255-261, 2000.

[6] D. F. D. F. de Souza, C. G. M. de Souza, and R. M. Peralta, "Effect of easily metabolizable sugars in the production of xylanase by Aspergillus tamarii in solid-state fermentation," Process Biochemistry, vol. 36, no. 8-9, pp. 835-838, 2001.

[7] E. Kalogeris, P. Christakopoulos, D. Kekos, and B. J. MacRis, "Studies on the solid-state production of thermostable endoxylanases from Thermoascus aurantiacus: characterization of two isozymes," Journal of Biotechnology, vol. 60, no. 3, pp. 155-163, 1998.

[8] A. Sunna and G. Antranikian, "Xylanolytic enzymes from fungi and bacteria," Critical Reviews in Biotechnology, vol. 17, no. 1, pp. 39-67, 1997.

[9] A. S. Ball and A. J. McCarthy, "Saccharification of straw by Actinomycete enzymes," Journal of Applied Bacteriology, vol. 66, pp. 439-444, 1989.

[10] W. Liu, W. Zhu, Y. Lu, J. Kong, and G. Ma, "Production, partial purification and characterization of xylanase from Trichosporon cutaneum SL409," Process Biochemistry, vol. 33, no. 3, pp. 331-336, 1998.

[11] A. L. D. S. Querido, J. L. C. Coelho, E. F. de Araújo, and V. M. Chaves-Alves, "Partial purification and characterization of xylanase produced by Penicillium expansum," Brazilian Archives of Biology and Technology, vol. 49, no. 3, pp. 15161523, 2006.
[12] E. T. Chivero, A. N. Mutukumira, and R. Zvauya, "Partial purification and characterisation of a xylanase enzyme produced by a micro-organism isolated from selected indigenous fruits of Zimbabwe," Food Chemistry, vol. 72, no. 2, pp. 179$185,2000$.

[13] M. Somogyi, "A new reagent for the determination of sugars," Journal of Biological Chemistry, vol. 160, pp. 61-68, 1945.

[14] M. Megharaj, S. Avudainayagam, and R. Naidu, "Toxicity of hexavalent chromium and its reduction by bacteria isolated from soil contaminated with tannery waste," Current Microbiology, vol. 47, no. 1, pp. 51-54, 2003.

[15] D. Jones, "A numerical taxonomic study of coryneform and related bacteria," Applied Microbiology, vol. 2, pp. 309-318, 1975.

[16] W. Wizani, H. Esterbauer, W. Steiner, and J. Gomes, "Preparation of xylanase by cultivating Thermomyces lanuginosus DSM 5826 in a medium containing corn cobs," US Patent 5183753, 1990.

[17] G. L. Miller, "Use of dinitrosalicylic acid reagent for determination of reducing sugar," Analytical Chemistry, vol. 31, pp. 538-542, 1959.

[18] R. Khandeparkar and N. B. Bhosle, "Purification and characterization of thermoalkalophilic xylanase isolated from the Enterobacter sp. MTCC 5112," Research in Microbiology, vol. 157, no. 4, pp. 315-325, 2005.

[19] S. W. Kang, Y. S. Park, J. S. Lee, S. I. Hong, and S. W. Kim, "Production of cellulases and hemicellulases by Aspergillus niger KK2 from lignocellulosic biomass," Bioresource Technology, vol. 91, no. 2, pp. 153-156, 2004.

[20] R. Muthechilan, R. Ashok, and S. Jayalakshmi, "Production and optimization of thermostable alkaline xylanase by Pencillium oxalicum in solid-state fermentation," African Journal of Microbiology Research, pp. 20-28, 2007.

[21] Q. K. Beg, M. Kapoor, L. Mahajan, and G. S. Hoondal, "Microbial xylanases and their industrial applications: a review," Applied Microbiology and Biotechnology, vol. 56, no. 3-4, pp. 326-338, 2001.

[22] C. Techapun, N. Poosaran, M. Watanabe, and K. Sasaki, "Thermostable and alkaline-tolerant microbial cellulase-free xylanases produced from agricultural wastes and the properties required for use in pulp bleaching bioprocesses: a review," Process Biochemistry, vol. 38, no. 9, pp. 1327-1340, 2003.

[23] M. A. Bim and T. T. Franco, "Extraction in aqueous twophase systems of alkaline xylanase produced by Bacillus pumilus and its application in kraft pulp bleaching," Journal of Chromatography B, vol. 743, no. 1-2, pp. 349-356, 2000.

[24] M. J. Tseng, M. N. Yap, K. Ratanakhanokchai, K. L. Kyu, and S. T. Chen, "Purification and characterization of two cellulase free xylanases from an alkaliphilic Bacillus firmus," Enzyme and Microbial Technology, vol. 30, no. 5, pp. 590-595, 2002.

[25] A. Dhillon, J. K. Gupta, B. M. Jauhari, and S. Khanna, "A cellulase-poor, thermostable, alkalitolerant xylanase produced by Bacillus circulans $\mathrm{AB} 16$ grown on rice straw and its application in biobleaching of eucalyptus pulp," Bioresource Technology, vol. 73, no. 3, pp. 273-277, 2000.

[26] R. D. S. Khandeparkar and N. B. Bhosle, "Isolation, purification and characterization of the xylanase produced by Arthrobacter sp. MTCC 5214 when grown in solid-state fermentation," Enzyme and Microbial Technology, vol. 39, no. 4, pp. 732-742, 2005.

[27] P. Sá-Pereira, M. Costa-Ferreira, and M. R. Aires-Barros, "Enzymatic properties of a neutral endo-1,3(4)- $\beta$-xylanase Xyl II from Bacillus subtilis," Journal of Biotechnology, vol. 94, no. 3, pp. 256-275, 2002. 
[28] A. Archana and T. Satyanarayana, "Xylanase production by thermophilic Bacillus licheniformis A99 in solid-state fermentation," Enzyme and Microbial Technology, vol. 21, no. 1, pp. 12-17, 1997.

[29] J. X. Heck, S. H. Flôres, P. F. Hertz, and M. A. Z. Ayub, "Optimization of cellulase-free xylanase activity produced by Bacillus coagulans BL69 in solid-state cultivation," Process Biochemistry, vol. 40, no. 1, pp. 107-112, 2005.

[30] S. L. Wang, Y. H. Yen, I. L. Shih et al., "Production of xylanases from rice bran by Streptomyces actuosus A-151," Enzyme and Microbial Technology, vol. 33, no. 7, pp. 917-925, 2003.

[31] K. Virupakshi, K. L. Kyu, and M. Tanticharoen, "Purification and properties of a xylan-binding endoxylanase from alkaliphilic Bacillus sp. strain K-1," Applied and Environmental Microbiology, vol. 65, pp. 694-697, 2005.

[32] S. Nakamura, K. Wakabayashi, R. Nakai, R. Aono, and K. Horikoshi, "Purification and some properties of an alkaline xylanase from alkaliphilic Bacillus sp. strain 41M-1," World Journal of Microbiology and Biotechnology, vol. 59, no. 7, pp. 2311-2316, 1993.

[33] T. Cesar and V. Mrša, "Purification and properties of the xylanase produced by Thermomyces lanuginosus," Enzyme and Microbial Technology, vol. 19, no. 4, pp. 289-296, 1996.

[34] L. P. M. Castro, B. A. Trejo-Aguilar, and G. A. Osorio, "Thermostable xylanases produced at $37^{\circ} \mathrm{C}$ and $45^{\circ} \mathrm{C}$ by a thermotolerant Aspergillus strain," FEMS Microbiology Letters, vol. 146, no. 1, pp. 97-102, 1997.

[35] N. B. Ghanem, H. H. Yusef, and H. K. Mahrouse, "Production of Aspergillus terreus xylanase in solid-state cultures: application of the Plackett-Burman experimental design to evaluate nutritional requirements," Bioresource Technology, vol. 73, no. 2, pp. 113-121, 2000. 

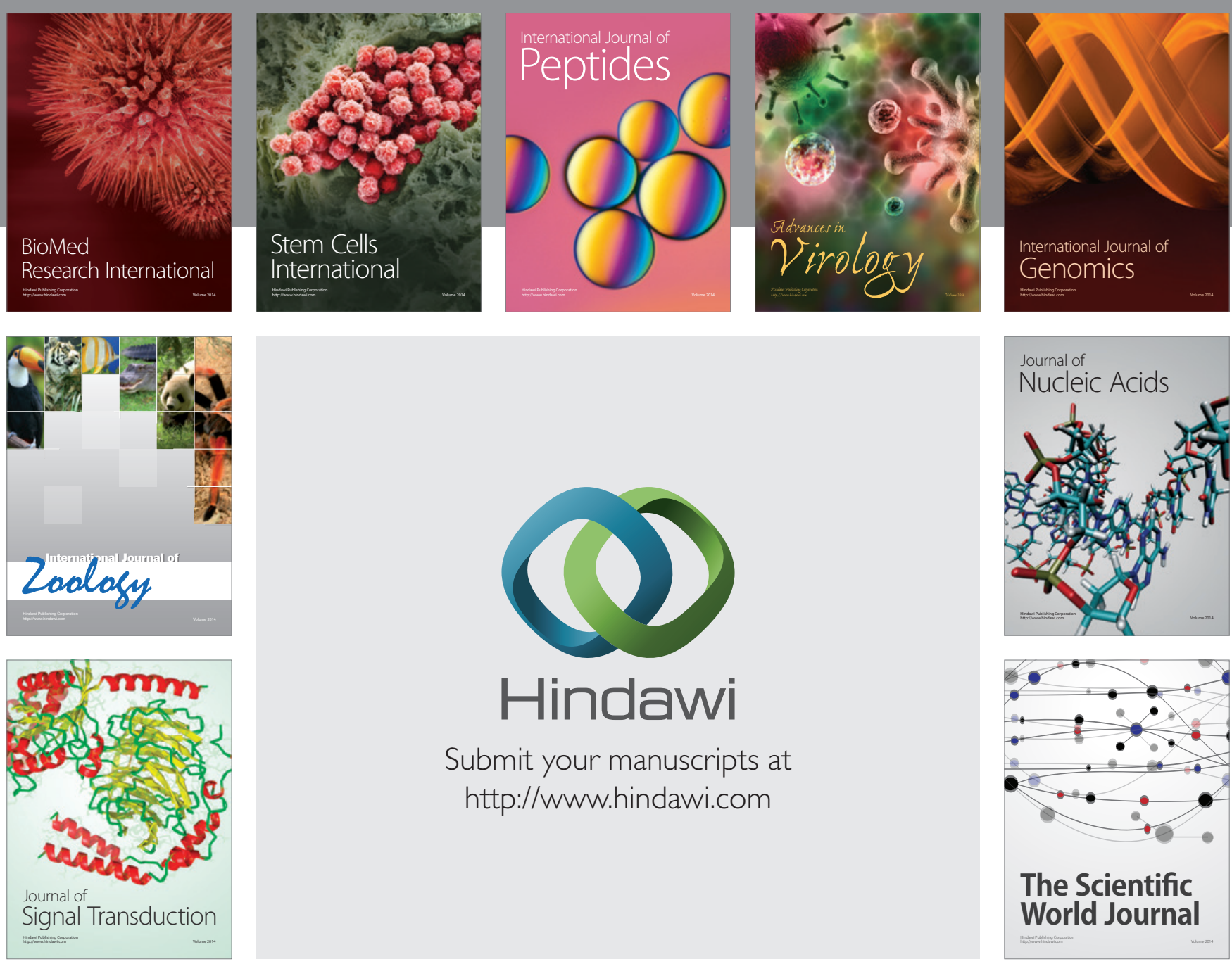

Submit your manuscripts at

http://www.hindawi.com
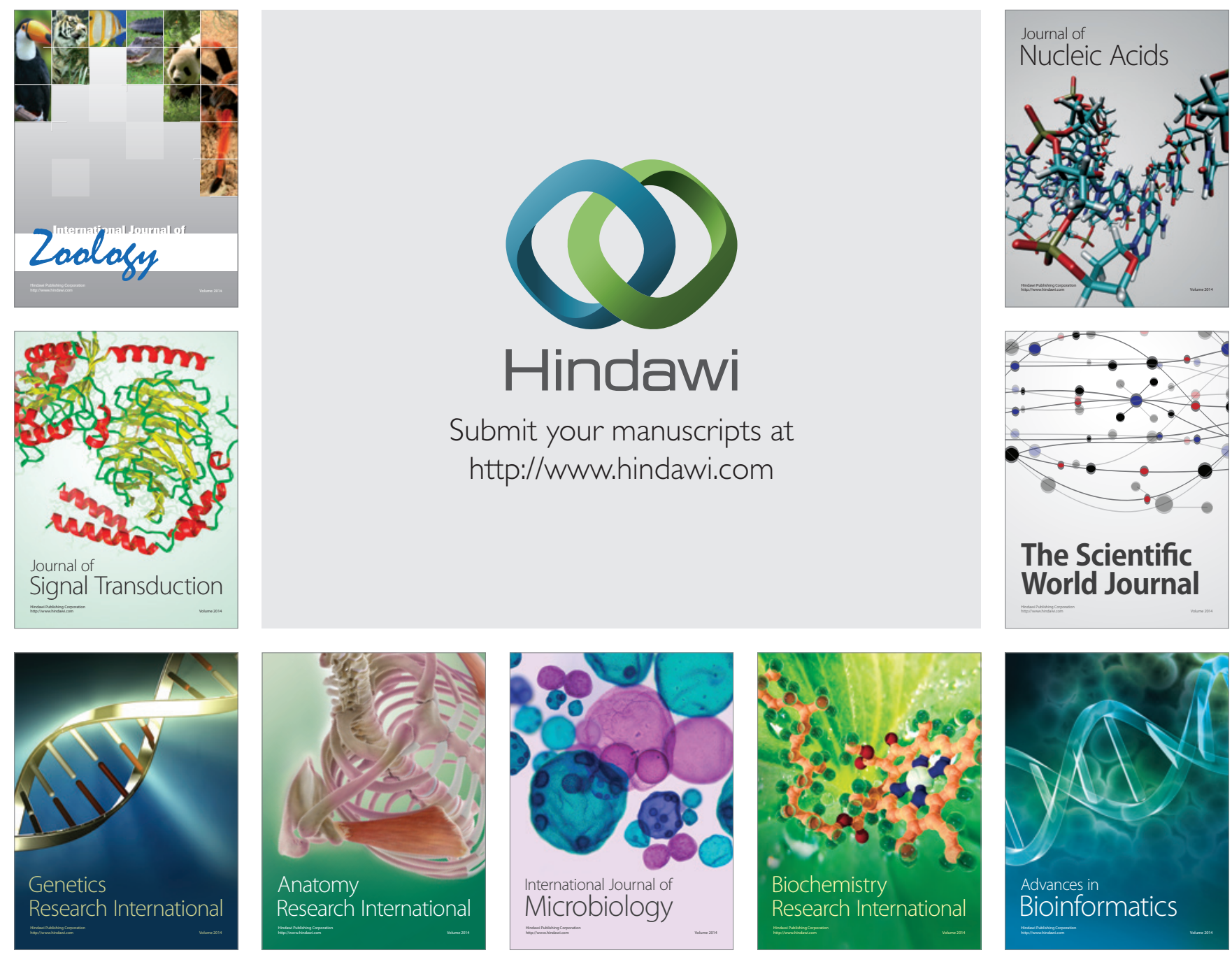

The Scientific World Journal
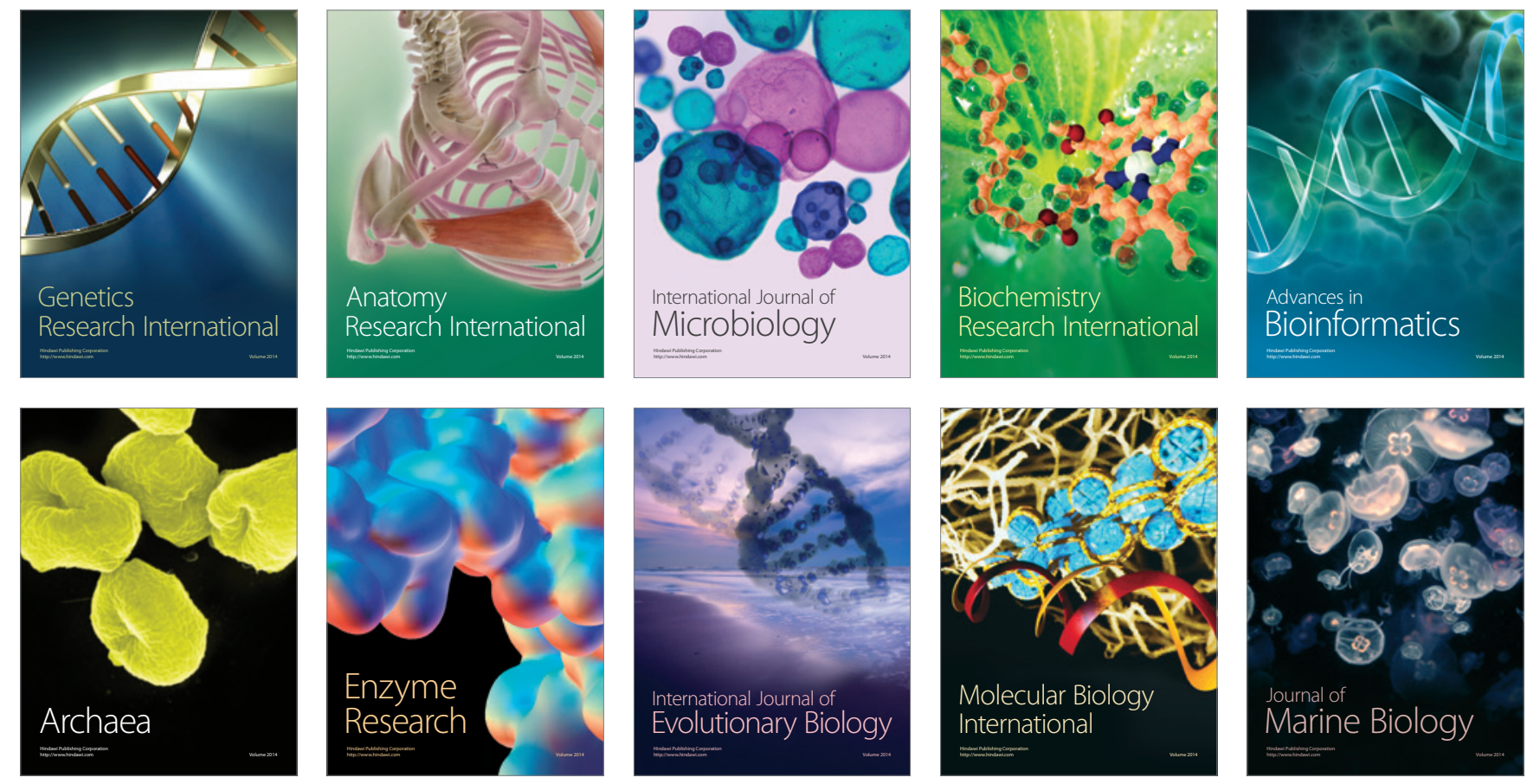